\title{
Introduction Forms of Time-Space (Chronotope) in Poetry
}

In the beginning God created the heaven and the earth.

And the earth was without form, and void;

And darkness was upon the face of the deep

And the Spirit of God moved upon the face of the waters.

And God said, Let there be light: and there was light.

And God saw the light, that it was good:

And God divided the light from the darkness.

And God called the light Day,

And the darkness he called Night.

And the evening and the morning were the first day.

Genesis I: I-5

Hear the voice of the Bard!

Who Present, Past, and Future sees

Whose ears have heard,

The Holy Word,

That walk'd among the ancient trees.

William Blake

This book explores the changing perception of time and space $\mathcal{L}$ in avant-garde, modernist, and contemporary poetry. I seek to characterize the works of modern Russian, French, and AngloAmerican poets based on the attitudes towards reality, time, space, and history revealed in their poetics. I also aim to identify crucial differences between poets from the same artistic movement (for example, the Italian and Russian futurists, especially the major 
Russian futurists Velimir Khlebnikov and Vladimir Mayakovsky). In my approach, I use Mikhail Bakhtin's idea of the chronotope and apply it to poetry. Although Bakhtin in his seminal work The Forms of Time and of the Chronotope in the Novel applies the chronotope only to prose, disregarding other genres or arts, or even culture in general, ${ }^{\mathrm{I}}$ it is my contention that time and space play a more crucial role in poetry, even in lyric poetry, since poetry can be defined as time and space condensed in images.

The idea of time and space is associated in human consciousness with the mythic separation of "the light from the darkness" and of "the waters from the waters." We can trace the development of time-space relations from the book of Genesis, Gilgamesh, The Elder Edda, and the Homeric epics, through Dante and Milton, and finally to modern poetry.

Time and language are closely connected. As George Steiner asserts in After Babel,

Every language-act has a temporal determinant. No semantic form is timeless. When using a word we wake into resonance, as it were, its entire previous history. A text is embedded in specific historical time; it has what linguists call a diachronic structure. To read fully is to restore all that one can of the immediacies of value and intent in which speech actually occurs. ${ }^{2}$

Combining what one might call the synchronic and diachronic approaches in modern literary theory, Steiner summarizes: "Language itself [. . .] is the most salient model of Heraclitean flux. It alters at every moment in perceived time." 3 Steiner's examples reveal the crucial interrelations between language, time, and history: "The grammar of

I Mikhail Bakhtin, "Forms of Time and of the Chronotope in the Novel," in The Dialogic Imagination, ed. Michael Holquist, trans, Caryl Emerson and Michael Holquist (Austin: University of Texas Press, I981), 84-258.

2 George Steiner, After Babel: Aspects of Language and Translation (Oxford: Oxford University Press, I975), 24.

3 Steiner, After Babel, I8. 
the Prophets in Isaiah enacts a profound metaphysical scandal-the enforcement of the future tense, the extension of language over time. A reverse discovery animates Thucydides; his was the explicit realization that the past is a language-construct, that the past tense of the verb is the sole guarantor of history." 4

Time, one of the most important philosophical ideas of humanity, serves as a powerful poetic motive in the history of world literature and is always a potent device in the structural formation of a literary work. In his book The Culture of Time and Space, Stephen Kern shows how the introduction of the wireless, the telephone, and other technological inventions, as well as the increase of speed and the appearance of Einstein's special (I905) and general (I9I6) theories of relativity, changed the human perception of time and space. ${ }^{5}$

Another impact on human consciousness of technological inventions such as the telegraph, telephone, and airplane was that a resident of a big European city realized that there were five billion people on earth, and the sense of multitude was reflected by individual consciousness: a person felt that one was dissolved in that multitude and lost one's "ego" and privacy. The Russian critic Leonid Dolgopolov wrote in his essay on Andrei Bely's novel Petersburg, "in Gogol's and, especially, in Dostoyevsky's novels man began to lose himself and dissolved the uniqueness of his 'ego' in the life that surrounded him." Raskolnikov's life was already the "life of the street, of the city, of the whole mankind: the boundary between his room without a lounge and the street was conventional."7

The idea of relativism was already present in Russia at the end of the nineteenth century: the separation between time and space was being smothered, dissolved in the consciousness of people who lived in big Russian cities, to say nothing of those who lived in Western

4 Ibid., 22.

5 Stephen Kern, The Culture of Time and Space (Boston: Harvard University Press, I983), I9.

6 Leonid Dolgopolov, "Roman Andreia Belogo 'Peterburg," in Peterburg, by Andrei Belyi (Moscow: Nauka Publishing House, I98I), 588.

7 Ibid. 
Europe. Time is the fourth dimension of space, as Stephen Kern asserts in The Culture of Time and Space. ${ }^{8}$

In The Forms of Time and of the Chronotope in the Novel, Mikhail Bakhtin proposes the term "chronotope." As he puts it, "this term [time-space, or, chronotope] is employed in mathematics, and was introduced as part of Einstein's Theory of Relativity."9 Bakhtin applied this term to literary theory as a metaphor (he himself mentions in parentheses that it is "almost, but not entirely" a metaphor for him ${ }^{\mathrm{I}}$ ). The idea of the unity of time and space-time as the fourth dimension of space-was most relevant for him. Bakhtin understood the chronotope as a "category of literature with its own significance in form and content." ${ }^{\prime \prime}$

Bakhtin discusses the time-space relationship and applies the chronotope only to prose, not to other genres, or to arts or culture in general. Time in literature is condensed, and therefore becomes more artistically vivid and notable; space, in turn, is intensified as it becomes a deeper part of the movement of time, plot, and history. ${ }^{12}$ (This phenomenon was noticed by Viktor Shklovsky much earlier than by Bakhtin.) ${ }^{\mathrm{r} 3}$ The features and images of time are revealed through space, and space, in turn, is comprehended and measured by time. The chronotope in literature is thus characterized by this intersection and interrelation of sequences and by the junction of these features (time and space). Bakhtin states that "genre and generic distinctions [varieties]" ${ }_{4} 4$ are defined by the chronotope: "the chronotope as a formal constitutive category determines to a

8 Kern, The Culture of Time and Space, I45, 206.

9 Bakhtin, "Forms of Time and of the Chronotope," 84.

Io Ibid.

I I Mikhail Bakhtin, Voprosy literatury i estetiki (Moscow: Khudozhestvenaia literatura, I975), 235. Translation is mine.

I 2 Bakhtin, Voprosy, 235.

I 3 Viktor Shklovsky, "The Connection between Devices of Syuzhet Construction and the General Stylistic Devices," in Russian Formalism, ed. Stephen Bann and John Bowlt, trans. Jane Knox (Edinburgh: Scottish Academic Press, I973), 58-6r.

I4 Bakhtin, "Forms of Time and of the Chronotope," 85. 
significant degree the image of man in literature as well. The image of man is always intrinsically chronotopic." I5

Bakhtin extends the meaning of the chronotope and applies it to such categories as the chronotope of reality, the chronotope of the road, the chronotope of love, and so on. He shows the development of the forms of the chronotope only in the novel, but, as was stated by Roman Jakobson in "Dialogue on Time in Language and Literature" with Krystyna Pomorska, the notion of time is one of the most relevant and dominant features in poetry. Discussing the heritage of the Polish classical philologist Tadeusz Zielinski (I859-1944), who revealed essential instances of time-space relations in the Iliad, Jakobson comes to the conclusion that "the most effective experience of verbal time occurs in verse [. . .] which simultaneously carries within it both linguistic varieties of time: the time of the speech event and that of the narrated event" (my emphasis). ${ }^{\mathrm{I}}$

It is my contention that the chronotope is crucial to our understanding of literary movements and of individual poets, and we can trace it from ancient to modern poetry. Tracing the chronotope and connecting it with history are the objectives of this book.

In neoclassical poetry, the flux of time is a more or less successive movement with a beginning, past, present, and future (though time may be condensed or reversed). In the poetry of the younger romantics, however, especially Shelley, we have, using the metaphors of Bergson, "the invisible progress of the past gnawing into the future, [. . .] the continuous progress of the past which gnaws into the future and which swells as it advances." ${ }^{17}$ In Shelley's "Mont Blanc" (I8I6), where "primaeval mountains / Teach the adverting mind," ${ }^{18}$ the primeval past leaves its footprint on nature. Shelley can see the primeval past in the present time, which for him

I5 Ibid., 85 .

I6 Roman Jakobson, Verbal Art, Verbal Sign, Verbal Time (Minneapolis: University of Minnesota Press, I985), 2I-22.

I7 Henri Bergson, Matter and Memory (New York: Doubleday, I959), 52-53.

I8 Percy Bysshe Shelley, "Mont Blanc," in Shelley's Poetry and Prose, ed. Donald H. Reiman and Sharon B. Powers (New York: Norton, 1977), 92. 
is prolonged into space and the universe. The boundaries of time and space do not exist for him: they are like a multi-folded fan. He easily travels from one reality to another (here Shelley anticipates both the theory of relativity and José Ortega y Gasset's perspectivism) and can see how "the old Earthquake-daemon taught her young Ruin." I9 As Shelley himself writes in "A Defence of Poetry," quoting Francis Bacon, "the same footsteps of nature impressed upon the various subjects of the world." ${ }^{20}$ For Shelley, a poet "not only bebolds the present as it is, and discovers those laws according to which present things ought to be ordered, but he beholds the future in the present, and his thoughts are the germs of the flower and the fruit of latest time" (my emphasis). ${ }^{2 I}$

In emphasizing this anticipation of the future, both Ortega y Gasset $^{22}$ and Renato Poggioli ${ }^{23}$ called the romantics the predecessors of modernism. As Jakobson stated, "the romantics are often described as explorers of man's spiritual realm and poets of emotional experience, but as a matter of fact the contemporaries of the romantics thought of the movement exclusively in terms of its formal innovations. They observed first of all the destruction of the classical unities." 24 In the poetry of the romantics, the relations between art and life were forever changed. They made time, space, and reality palpable by breaking with the classical tradition of personifying abstract ideas, human virtues, and evils, and by turning to subjective reality: the micro-world of feelings, not only of the past, but also of the present and the future. Along with this revolution against accepted ideas, the romantics broke the old forms as well, the exhausted intonational

i9 Shelley, "Mont Blanc," 9r.

20 Percy Bysshe Shelley, "A Defence of Poetry," in Shelley's Poetry and Prose, 482.

2 I Shelley, "A Defence of Poetry," 482-83.

22 See José Ortega y Gasset, The Dehumanization of Art and Other Essays on Art, Culture, and Literature (Princeton: Princeton University Press, 1968).

23 See Renato Poggioli, The Theory of the Avant-Garde (Cambridge, MA: The Belknap Press of Harvard University Press, I968).

24 Roman Jakobson, "Modern Russian Poetry: Velimir Khlebnikov," in Major Soviet Writers, ed. Edward J. Brown (New York: Oxford University Press, I973), 63. 
and lexical-semantic structures that had been automatized by the epigones. They shook the old rhythms and used old forms to express new content.

A similar revolution took place in avant-garde and modernist literature at the beginning of the twentieth century. Both Stephen Kern and Marjorie Perloff write about this new perception of time and space in twentieth century literature. It is crucial, in my view, that both the French avant-garde poets and the Russian futurists eliminated the separation between the past, the present, and the future as well as between space and time.

In his otherwise brilliant book The Culture of Time and Space, Stephen Kern is mostly concerned with ideas, and he uses literature, including poetry, mainly to illustrate his point of view. For Kern, there is little difference between the works of Apollinaire, Cendrars, and Barzun, since for him they all put forth fascinating ideas like simultaneity, as will be discussed in the following chapter. Marjorie Perloff in her illuminating book The Futurist Moment is mainly concerned with the problem of form, but the differences between the works of two innovators, Aleksei Kruchonykh (I886-I968) and Velimir Khlebnikov (I885-I922), who both put forward the idea of zaum' or beyonsense (trans-sense) language, ${ }^{25}$ are unclear, as is the reason why Kruchonykh, who lived on for forty-six years after the death of Khlebnikov, never created anything equally innovative. I presume it was due to the fact that Kruchonych was concerned mostly with form, limiting his search to philology and unable to go beyond it. In contrast, the greatness of Khlebnikov's genius eventually became clear even to the average reader.

I believe that the interpretation of literature should be neither reduced to the analysis of form nor to hermeneutics alone. The interpretation of what is hidden behind the word of an image-picture should go alongside analyses of the intonational systems of different

25 Velimir Khlebnikov, Collected Works, ed. Charlotte Douglas and trans. Paul Schmidt, vol. I, Letters and Theoretical Writings (Cambridge, MA: Harvard University Press, I987), I47. 
poets, their stylistic devices, diction, and so on. In other words, I advocate an approach that interprets the poetic motives rather than the meaning or the form of the poems. These analyses of poets' views of reality, history, and time-space relations should ideally include analyses of artistic personalities.

The notion of "poetic motive" has been developed in Russian literary theory by Alexander Veselovsky, Boris Tomashevsky, and Boris Gasparov. ${ }^{26}$ Vladimir Toporov's and Eleazar Meletinsky's works should be also added to this list. ${ }^{27}$ In his first known article of r9r9, "Iskusstvo i otvetstvennost"” ("Art and Responsibility"), Mikhail Bakhtin states, "the three spheres of human culturescience, art, and life-are unified only by the personality of the artist that joins them together in the union." ${ }_{28}^{8}$ Bakhtin further discusses the discrepancy between the personality of the artist in art and in life and concludes that "it is solely the unity of responsibility" that guarantees the intrinsic unity of the artistic personality: "I have to be accountable with my entire life for everything that I have experienced and understood in art, so that it [everything that I realized and experienced] should not be wasted." 29

The classical scholar Sergey Averintsev (1937-2004) differentiates between the notions of "the author ('auctor' - nomen augentis, i.e. denomination of the subject of an action)" and "auctoritas ('authority' -

26 Alexander Veselovskii, Istoricheskaya poetika (Moscow: Vysshaya Shkola, I989); Boris Tomashevskii, Teoriya literatury: Poetika (Moscow: Aspect Press, 1999); Boris Gasparov, Literaturnye leitmotivy (Moscow: Nauka, I994) and Poetika "Slova o polku Igoreve" (Moscow: Agraf, 200o). In his otherwise thoughtful and insightful study of the Poetics of the Tale of Igor's Campaign, Boris Gasparov studies each motif separately as in Vladimir Propp's Morfologiia skazki (Leningrad: Academia, I928).

27 Vladimir Toporov, Mif. Ritual. Simvol. Obraz. Issledovaniia v oblasti mifopoeticheskogo (Moscow: Progress, 1995); and Eleazar Meletinskii, Poetika mifa (Moscow: Nauka, I976).

28 Mikhail Bakhtin, "Art and Responsibility," in Literaturno-kriticheskie stat'i (Moscow: Khudozhestvennaia literatura, I986), 3. Translation is mine.

29 Bakhtin, "Art and Responsibility," 3. Translation is mine. 
denomination of a certain quality of the subject)." 30 Mentioning the problem of identifying the real authors of Psalms and Proverbs, Averintsev claims that the former nevertheless bears the name of King David, while the latter that of King Solomon. In both cases, the authority of the king has been institutionalized as the author, and that authority allows him to speak in the name of God. ${ }^{31}$ Averintsev also differentiates between Homer and Hesiod: although the latter spoke about himself in great detail in Labors and Days (633-40, 654-57), whereas very little is known about Homer's life, their primary difference does not lie in the scope of their biographies. Rather, as Averintsev illustrates, Hesiod's own words reveal the biggest distinction between the two: "We know enough to make up lies / Which are convincing, but we also have / The skill, when we've a mind, to speak the truth." ${ }^{2}$ Homer was an authority as a poet, an author; Hesiod pretended to utter the truth of the gods and of the community, not his own. Averintsev concludes that Hesiod shifted the epic from the heroic to the didactic. 33 In other words, based on a new poetic motive, Hesiod put forth a new poetic style (although, of course, this is not to suggest that Hesiod was a better poet than Homer).

In his work "Poetic Motive and Context"-which develops the notion of German philosopher Wilhelm Dilthey (I833-I9II) that the motif is the poetic approach to life and reality in all its complexityRussian scholar, poet, and translator Vladimir Mikushevich states, "art begins with an approach towards life, with a substance [. . .]. Yet we need a personality for the poetical comprehension of this relation. Personality and substance are the two sides of a poetic motive." ${ }^{34}$ I understand the motive of an artistic work as the integrity of the main theme-something

30 Sergei Averintsev, "Avtorstvo i avtoritet," in Istoricheskaia poetika (Moscow: Nasledie, I994), I05. Translation is mine.

3I Averintsev, "Avtorstvo i avtoritet," rog. Translation is mine.

32 Dorothea Wender, trans., Hesiod and Theognis (London: Penguin, I973), 24.

33 Averintsev, "Avtorstvo i avtoritet," I I9.

34 Vladimir Mikushevich, "Poeticheskii motiv i kontekst," in Voprosy teorii budozhestvennogo perevoda (Moscow: Khudozhestvennaya literatura, I97I), 4I. 
that induces the artist to act-as well as the philosophical, ethical, and aesthetic approach of the artistic personality to reality.

It is crucial to trace the artistic realization of the poetic motive only in definite contexts. These two planes are united by the personality of the verbal artist who simultaneously belongs to life (reality A) and to art (reality B), which is not necessarily a "reflection" or mimetic representation, but is rather the creation of another reality with the help of artistic devices or orudiinye sredstva (weapons), as Osip Mandelstam put it. ${ }^{35}$ The execution of a poetic motive is its lexical, syntactical, and rhythmical (or metrical, if we consider the traditional system of versification) realization in the specific context of the literary work. The poetic motive is evoked or realized only in this specific context, since words can acquire meanings only in contexts, not in the dictionary.

The context of a poetic work is the "speaking picture," to quote Sir Philip Sidney, ${ }^{36}$ or the "plastic space" in which a poetic motive is realized or evoked. ${ }^{37}$ The Russian scholar Boris Eikhenbaum defines melodics as an intonational system, that is, "a combination of intonational figures or movements as they are revealed in a definite syntax." ${ }^{8}$ If we extend this definition, we come to the conclusion that the intonational system is the unity of the poet's personal tone, rhythm, meter (in traditional systems of versification), diction, and stylistic devices realized in a definite syntax (including the composition of the piece) in the process of realization of the poetic motif in the context of a specific literary work.

In this book, I seek to characterize the works of modern poets based on their attitudes towards reality, time, space and history revealed in their poetics. In the following chapters I will show both similarities

35 Osip Mandel'shtam, "Razgovor o Dante," in Sochineniia v dvukh tomakh, ed. Pavel Nerler (Moscow: Khudozhestvennaia literatura, I990), 2:2 I 4.

36 Sir Philip Sidney, "The Defense of Poesie," in Selections from Arcadia and Other Poetry and Prose, ed. T. W. Craik (New York: Capricorn, I966), 27.

37 This is the expression of the prominent Russian poet, artist, and the best translator of Milton's Paradise Lost into Russian-Arkady Shteinberg (1907-1984).

38 Boris Eikhenbaum, O poezii (Leningrad: Sovetskii pisatel', I969), 338. Translation is mine. 
between the poets from different artistic movements (as for instance, the attitude towards time and space of Apollinaire and Mayakovsky) and crucial differences between the French avant-garde poets (Barzun, Cendrars, and Apollinaire), Italian and Russian futurists, or with the major Russian futurists Velimir Khlebnikov and Vladimir Mayakovsky. The attitude towards time, space, and history is equally important for W. B. Yeats, Osip Mandelstam, Ezra Pound, and T. S. Eliotrevealing both similarities and differences of the poets "sailing after knowledge" in their spiritual quest - and, in spite of the postmodernist "estrangement" of reality, ${ }^{39}$ similar traces can be found in the work of contemporary American poets John Ashbery and Charles Bernstein.

39 I will continue to use the term "estrangement" or "defamiliarization," put forward by Victor Shklovsky (1893-1984) in his seminal "Iskusstvo kak priem" ("Art as Device" or "Art as Technique"), first published in volume 2 of Sborniki po teorii poeticheskogo iazyka (Collections [of Essays] on the Theory of Poetic Language) (Petrograd, I9I7), 3-I4. He considered "the device of defamiliarization" or estrangement as one of the main devices in literature aimed at a "shift" of meaning and perception in order to deautomatize them. It is possible that Gertrude Steinwho wrote, "A Rose is a rose is a rose" - and Ezra Pound, who drew his "make it new" from Chang $\mathrm{Ti}$ (the Chinese emperor of I $766 \mathrm{BC}$ ), came independently to the same idea. It will be most illuminating to see how Gertrude Stein's and Ezra Pound's ideas, merged with Shklovsky's "defamiliarization," were employed by the Language School of contemporary American poetry, discussed in the last chapter of the book. 
